\title{
A STUDY OF THE GLAZING TECHNIQUES AND PROVENANCES OF TANG SANCAI GLAZES USING ELEMENTAL AND LEAD ISOTOPE ANALYSES*
}

\author{
J. Y. SHEN, ${ }^{1}$ J. HENDERSON,${ }^{1,2} \dagger$ J. EVANS, ${ }^{3}$ S. CHENERY ${ }^{4}$ and F. Y. ZHAO ${ }^{5}$ \\ ${ }^{1}$ Department of Archaeology, University of Nottingham, University Park, Nottingham, NG7 2RD, UK \\ ${ }^{2}$ The University of Nottingham Ningbo China, No. 199, Taikang East Road, Ningbo, 315100, China \\ ${ }^{3}$ NERC Isotope Geosciences Laboratory, British Geological Survey, Keyworth, Nottingham, NG12 5GG, UK \\ ${ }^{4}$ Inorganic Geochemistry, British Geological Survey, Keyworth, Nottingham, NG12 5GG, UK \\ ${ }^{5} X i$ 'an archaeological institute of cultural relics protection, No. 68, Youyi West Road, Xi'an, 710068, China
}

\begin{abstract}
This study discusses the elemental compositions and lead isotope ratios of Tang sancai glazes unearthed from the Huangpu kiln, Huangye kiln and two Tang sancai tomb sites. The various glazes feature distinct lead isotope ratios and trace element characteristics, which can be interpreted as evidence for the use of different lead ore deposits and siliceous raw materials in the glazes. This is a strong indication that lead isotopes combined with trace element analysis could be used as a viable approach for identifying the provenance of Tang sancai of unknown origin by linking them to kiln sites, This provenance technique could be significant in the interpretation of ancient ceramic trade and communication patterns. In this study, the provenance of several Tang sancai glazes of uncertain origin were determined using this method: some Tang sancai wares unearthed in Xi' an City were produced in the kiln near Luoyang City and then traded to Xi' an City, providing an idea of ancient Tang sancai ceramic trade routes.

KEYWORDS: TANG SANCAI GLAZE, LEAD ISOTOPE ANALYSIS, TRACE ELEMENT ANALYSIS, PROVENANCE, HUANGPU KILN, HUANGYE KILN, TANG TOMBS
\end{abstract}

\section{INTRODUCTION}

Tang sancai, a type of multicoloured lead-glazed decorated ceramic ware, was produced during the Tang dynasty (AD 618-907). Sancai refers to its three dominant glaze colours, green, yellow and 'white' (actually colourless glaze on a white body), but the colours were not limited. Tang sancai ware, which is famous for its bright and exquisite glazed decoration, is often seen as the most significant type of low-fired glazed ceramic throughout Chinese ceramic history. Such wares were not only popular in China, where most Tang sancai wares have been excavated from Tang tomb sites, but also widely traded along the Maritime Silk Route from China, reaching many foreign lands: it has been found in present-day Japan, Sri Lanka, Iran, Egypt and Iraq (Rawson et al. 1989). Four kiln sites that once produced Tang sancai ceramics have been discovered: Huangye kiln (Gongyi City Institute of Cultural Relics 2000) in Henan province; Huangpu and Liquanfang kilns in Shaanxi province (Shaanxi Provincial Institute of Archaeology 1992, 2008); and Neiqiu kiln (Jia and Jia 1987) in Hebei province. The manufacturing techniques and provenances of Tang sancai are critical for the investigation of trade and technological developments in Tang sancai production centres. Previous studies have proven that different sources of clay raw materials were used in Tang sancai body pastes from these four kiln sites

*Received 6 March 2018; accepted 19 September 2018

$†$ Corresponding author: email julian.henderson@ nottingham.ac.uk

(c) 2018 The Authors Archaeometry published by John Wiley \& Sons Ltd on behalf of University of Oxford

This is an open access article under the terms of the Creative Commons Attribution-NonCommercial License, which permits use, distribution and reproduction in any medium, provided the original work is properly cited and is not used for commercial purposes. 
and they can be distinguished from one another using trace elemental analysis (Lei and Feng 2002; Lei et al. 2005, 2007; Miao and Lu 2001). However, only limited work has been done on the glazing techniques and provenances of Tang sancai glazes. The determination of major elemental compositions has shown that Tang sancai glaze belongs to the $\mathrm{PbO}-\mathrm{SiO}_{2}-\mathrm{Al}_{2} \mathrm{O}_{3}$ system coloured with Fe, Cu and Co (Feng et al. 2005; Zhang and Zhang 1980). Cui and Lei's (2009) pilot study showed that trace levels of $\mathrm{Ag}, \mathrm{Sb}, \mathrm{Ba}$ and $\mathrm{Sr}$ could be used to determine the provenance of Tang sancai yellow-coloured glazes produced at different kiln sites. Cui et al. (2010) then showed that lead isotope ratios of Tang sancai glazes could distinguish between Huangpu and Huangye kiln products.

To develop further an understanding of glazing techniques, the provenances of samples of unknown origin and the sources of raw materials used to make Tang sancai glazes, samples were investigated in the present study using a combination of major and trace elemental and lead isotope analysis. To date, the overwhelming majority of Tang sancai ceramic artefacts have been excavated as burial objects from Chinese Tang tombs, and most of these tomb sites were located near the two capitals of the Tang dynasty: Chang'an City (present-day Xi'an) in Shaanxi province and Luoyang City in Henan province (Jiang 2009, 21). Huangpu kiln in Shaanxi province and Huangye kiln in Henan province were the two main centres for Tang sancai production (Wood 2011, 203). In this paper, Tang sancai glazes produced in the Huangye and Huangpu kilns as well as Tang sancai glazes excavated from two Tang tomb sites in Xi' an City are investigated. The locations of the relevant sites are shown in Figure 1.

\section{SAMPLES}

Ten Tang sancai samples were obtained from the Huangpu kiln excavations in Tongchuan City in Shaanxi province, 10 were obtained from Huangye kiln in Gongyi City in Henan province and nine were obtained from two Tang tomb sites: the Chengnankeyunzhan Tang tomb (hereinafter referred to as the Nankezhan (NKZ) tomb) and the Weilaichubanshe (WL) Tang tomb, both located in Xi'an, Shaanxi province. The two Tang tomb sites are both dated to the Prospering period (649-756) of the Tang dynasty.

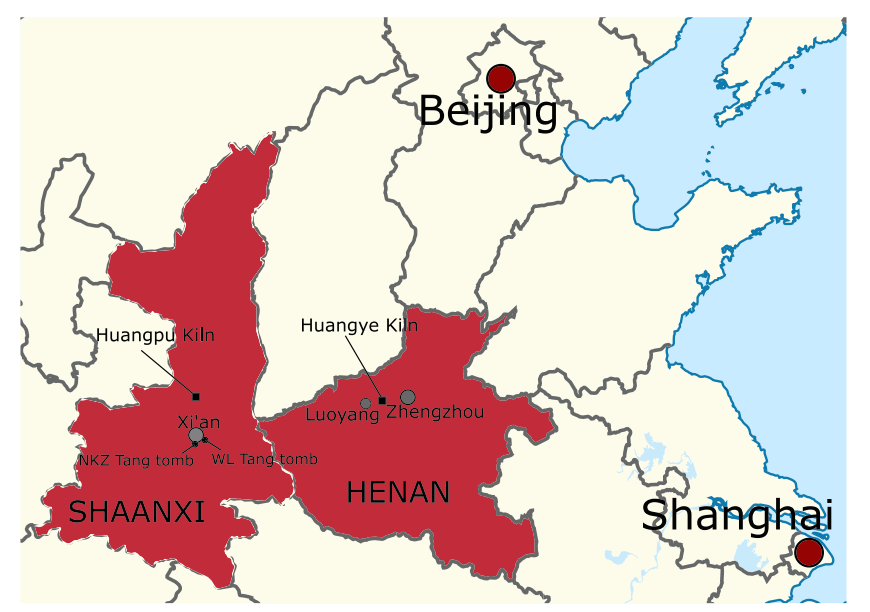

Figure 1 Locations of Tang sancai kiln sites and tomb sites: Nankezhan (NKZ) tomb and Weilaichubanshe (WL) tomb. [Colour figure can be viewed at wileyonlinelibrary.com] 
METHODS

\section{Chemical analysis}

The bulk elemental compositions of glazes were determined using a Cameca SX100 electron microprobe with four wavelength-dispersive spectrometers located in the Open University, UK. Small subsamples (around $5 \times 5 \mathrm{~mm}$ in area) were cut from each ceramic shard and mounted in cross-section in epoxy resin blocks. Each sample was analysed at least three times at $20 \mathrm{kV}$ accelerating voltage and $50 \mathrm{nA}$ incident beam current with a $50 \mu \mathrm{m}$ defocused electron beam. The counting time was $30 \mathrm{~s}$ on the peak $(20 \mathrm{~s}$ for $\mathrm{Na}$ ) and $20 \mathrm{~s}$ on the background ( $10 \mathrm{~s}$ for $\mathrm{Na}$. Analytical results were corrected for matrix effects using a commercial ZAF program. The Corning $\mathrm{C}$ reference glass was analysed as a secondary standard. The precisions of all elements analysed in this study were ideal with a relative standard deviation (RSD) of $<5 \%$.

The rare earth element (REE) concentrations of glazes were determined using a laser ablationinductively coupled plasma-mass spectrometry (LA-ICP-MS) instrument located in the Analytical Geochemical Laboratories of the British Geological Survey, Nottingham, UK. The NewWave UP193FX excimer $(193 \mathrm{~nm})$ laser system with a built-in microscope imaging system was used to ablate the sample. The chamber was flushed by a stream of He gas $\left(0.80 \mathrm{~L} \mathrm{~min}^{-1}\right)$, mixed with an argon carrier gas $\left(0.85 \mathrm{~L} \mathrm{~min}^{-1}\right)$, to an Agilent 7500 series ICP-MS. The laser ablation crater was set at $70 \mu \mathrm{m}$ in diameter and approximately $30 \mu \mathrm{m}$ deep; the laser was fired for $45 \mathrm{~s}$ on the sample at $10 \mathrm{~Hz}$ and a typical fluence of $2.8 \mathrm{~J} \mathrm{~cm}^{-2}$. Data were recorded in time-resolved analysis (TRA) mode. Each glaze sample was measured on three sampling positions in order to calculate the average for data evaluation.

Calibration of the system was performed using the standard reference glass NIST SRM610; NIST SRM612 was used for quality control. Calculations were performed using the Iolite (vers. 2.5) software. The known Si contents of glaze samples determined by electron probe microanalysis-wavelength dispersive spectrometry (EPMA-WDS) were used as an internal standard. Calibration and quality control were carried out by analyzing glass standard samples with each glaze sample block. The calculated RSDs of the replicate analyses of NIST SRM612 showed that accuracy and precision of the measurements were good and within expected values (2-5 RSD\% for a majority of elements).

\section{Lead isotope analysis}

Sample preparation For $\mathrm{Pb}$ isotope analysis of the glazes, the first step was to remove the glaze layer cleanly from the ceramic body. A diamond-edged dental saw was used; this leaves some body paste still attached to the glaze. In the next step, a tungsten carbide dental burr (DFS, Riedenber, Germany) was used to grind away the remaining ceramic body paste so as to leave a clean sample of glaze. Approximately $10 \mathrm{mg}$ of each glaze sample were placed in an acid-leached Teflon beaker and dissolved in 1-2 $\mathrm{ml}$ of Teflon distilled (TD) $\mathrm{HNO}_{3}$ and $29 \mathrm{M}$ HF. This was then converted to bromide form and passed through a Dowex AG1 anion resin column to collect the $\mathrm{Pb}$.

Isotope analysis Lead isotope analysis of these samples was conducted using a Nu Instuments Nu Plasma, MC-ICP-MS. Before analysis, each sample was spiked with a thallium (Tl) solution, which was added to allow for the correction of instrument-induced mass bias. Samples were then introduced into the instrument via an ESI $50 \mu 1 \mathrm{~min}^{-1}$ PFA micro-concentric nebulizer attached to a de-solvating unit (Nu Instruments DSN 100). Faraday collectors were configured to allow for 
the simultaneous detection of the following ion beams: ${ }^{204} \mathrm{~Pb},{ }^{206} \mathrm{~Pb},{ }^{207} \mathrm{~Pb}$ and ${ }^{208} \mathrm{~Pb}$. In addition, ${ }^{203} \mathrm{Tl}$ and ${ }^{205} \mathrm{Tl}$ (for mass bias correction) and ${ }^{202} \mathrm{Hg}$ to allow for correction of the ${ }^{204} \mathrm{Hg}$ interferant on ${ }^{204} \mathrm{~Pb}$ were set up for detection. Each individual acquisition consisted of 75 ratios, collected at 5-s integrations, following a 60-s defocused baseline.

The precision and accuracy of the method were assessed through repeat analysis of an NBS $981 \mathrm{~Pb}$ reference solution (also spiked with $\mathrm{Tl}$ ). The averages obtained for each of the mass bias-corrected NBS 981 ratios were normalized to the known values for this reference $(\mathrm{Pb}$ double-spike data were taken from Thirlwall 2002: ${ }^{206} \mathrm{~Pb} /{ }^{204} \mathrm{P}=16.9417,{ }^{207} \mathrm{~Pb} /{ }^{204} \mathrm{~Pb}=15.4996$, ${ }^{208} \mathrm{~Pb} /{ }^{204} \mathrm{~Pb}=36.724,{ }^{207} \mathrm{~Pb} /{ }^{206} \mathrm{~Pb}=0.91488$ and $\left.{ }^{208} \mathrm{~Pb} /{ }^{206} \mathrm{~Pb}=2.1677\right)$. Internal uncertainties (the reproducibility of the measured ratio) were propagated relative to the external uncertainty (i.e., the excess variance associated with the reproducibility of the NBS 981 reference material analysed during the session).

\section{RESULTS AND DISCUSSION}

\section{Major chemical compositions of Tang sancai glazes}

The major and minor chemical compositions of Tang sancai glaze and body samples unearthed from the Huangye and Huangpu kilns and two Tang tomb sites in Xi'an City are shown in Table 1.

\section{Colorants of Tang sancai glazes}

The colours of Tang sancai glaze samples in this study were limited to green, brown and 'white'. As can be seen in Table 1, the green glaze samples had the highest copper oxide $(\mathrm{CuO})$ content, ranging from 1.22 to $3.70 \mathrm{wt} \%$, showing that $\mathrm{CuO}$ is the colouring agent. In addition, several green glazes of Huangpu kiln Tang sancai (HPK-1, HPK-2, HPK-5, HPK-10) had a relatively high tin oxide $\left(\mathrm{SnO}_{2}\right)$ content $>0.2 \%$, showing that they were probably made by adding a small amount of a copper-tin compound to the glaze, and the most likely source for it would have been bronze. Most of the brown glazes had a relatively high iron oxide $(\mathrm{FeO})$ content ranging from 1.09 to $5.35 \mathrm{wt} . \%$. These brown glazes could also be divided into paler and darker brown variations. The paler brown ones had a relatively low $\mathrm{CuO}$ content $(0.06-0.78 \mathrm{wt} . \%)$, whereas the darker brown ones (HYK-9, NKZ-1, NKZ-2) had relatively high $\mathrm{CuO}$ contents: 1.06, 1.09 and 1.19 wt.\% respectively. This shows that $\mathrm{FeO}$ was used as a colouring agent in the pale brown glazes, while the darker brown colour was probably caused by a combination of $\mathrm{CuO}$ and $\mathrm{FeO}$. The colourless ('white') transparent part of the glaze contained the lowest levels of FeO and $\mathrm{CuO}$. Archaeological reports on Huangye and Huangpu kilns site excavations demonstrated that white kaolin was the main clay used for Tang sancai wares, mixed with smaller amounts of loessic clay (Shaanxi Provincial Institute of Archaeology 1992, 15; Sun 2002, 3, 10). The apparently 'white' colour of the sancai glaze is the colour of the high aluminium oxide $\left(\mathrm{Al}_{2} \mathrm{O}_{3}\right.$ ) (about 30\%) white kaolin clay body visible beneath the glaze. The clay was further characterized by low FeO levels of $<2.5 \%$ and significant levels of titanium dioxide $\left(\mathrm{TiO}_{2}\right)$ of about 1\% (Rawson et al. 1989). In some cases, there were intermediate areas of glaze with overlaps of different glaze colours: Tang sancai wares were often decorated by two or three glaze colours and these tended to run and mix together during the process of firing.

The $\mathrm{CuO}$ used was sourced either from processed copper ores, such as chalcopyrite and chalcocite, or from bronze. The FeO used might either have come from iron ores, such as 
Glazing techniques and provenances of Tang sancai glazes

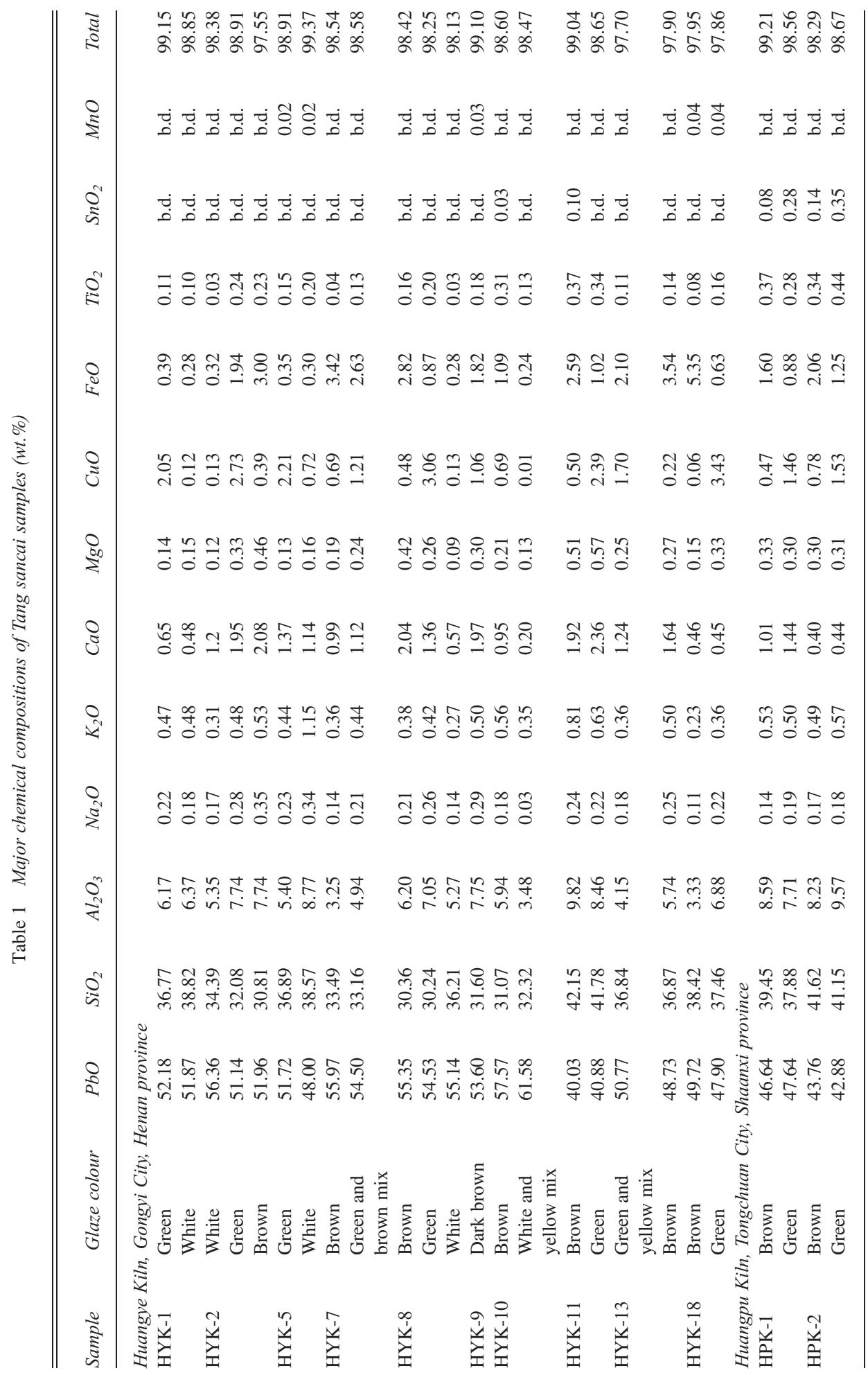


J. Y. Shen et al.

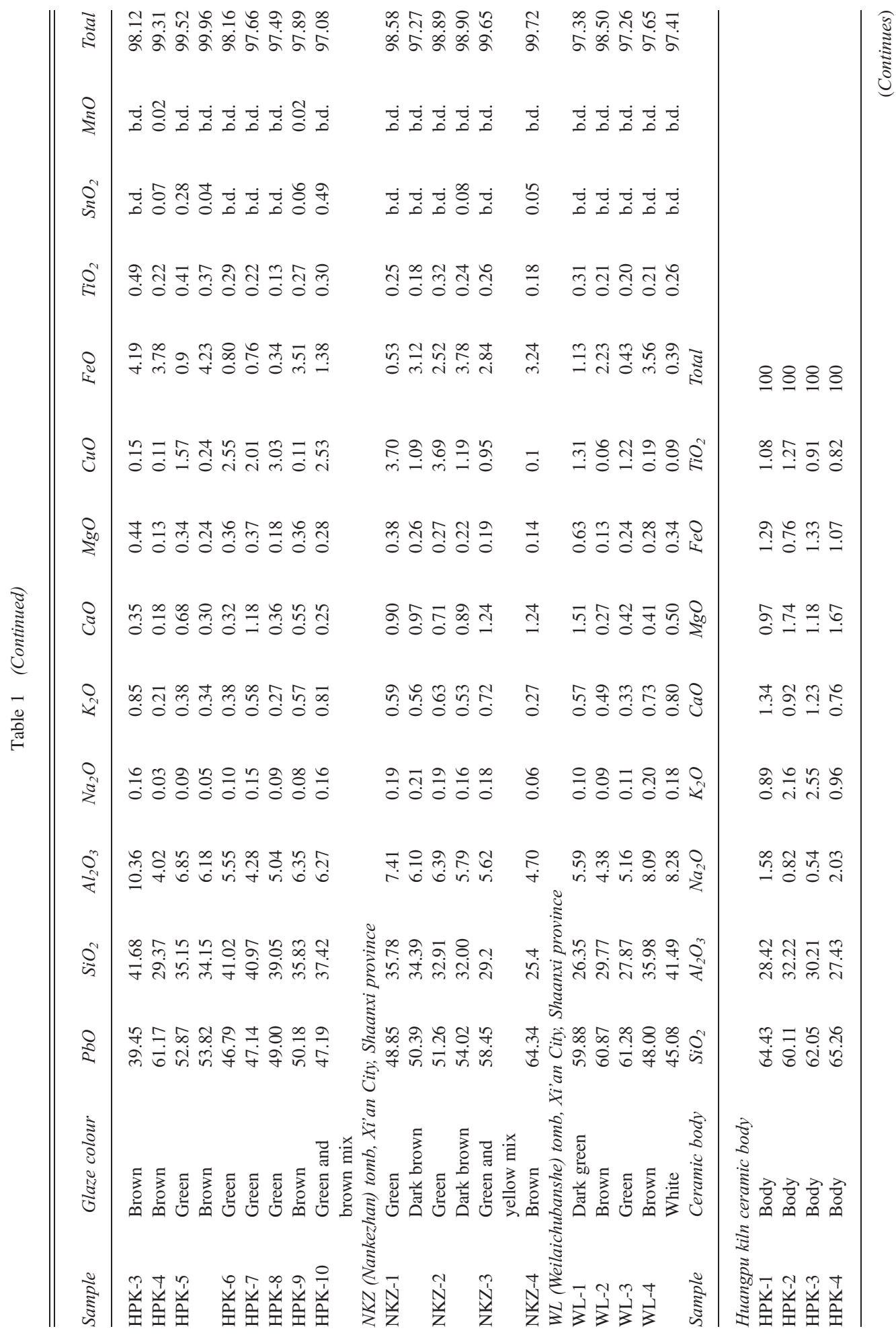




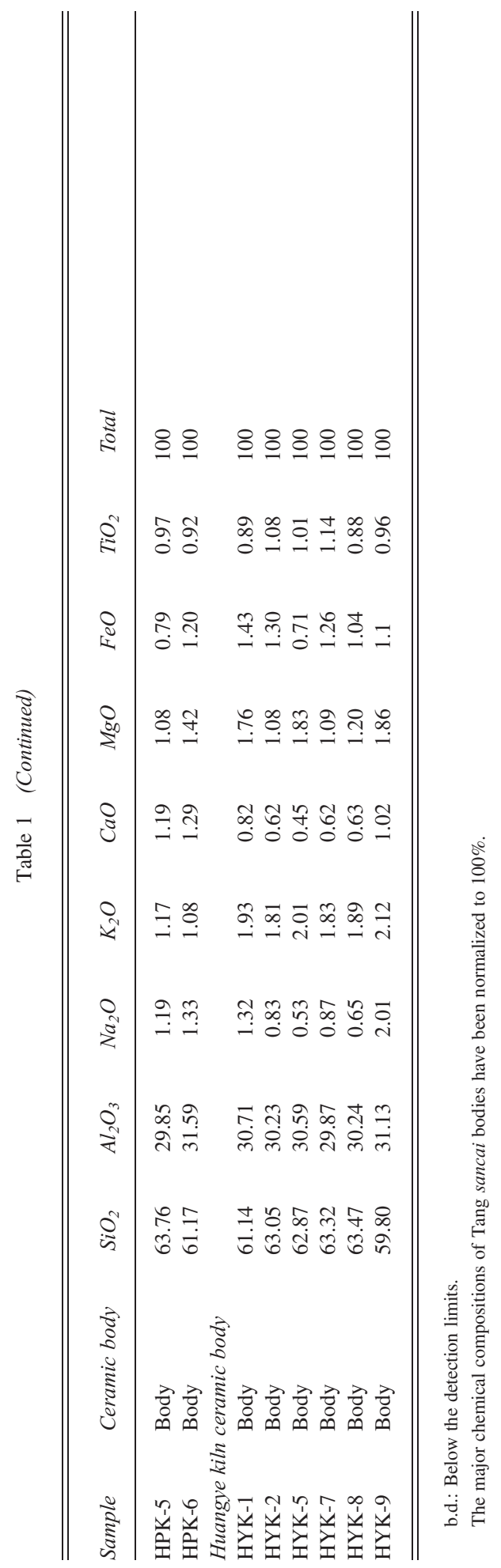


haematite and goethite, or iron-rich 'red earths'. The materials used to colour such glazes were transformed into very fine powders by crushing, powdering, grinding and sifting. A small amount of the finely powdered colorant was then mixed with prepared lead compound or a mixture of silica and lead compound to make the final glaze suspension (Watson 2014, 29).

\section{Glazing technique of Tang sancai lead glaze}

All the Tang sancai glaze samples contained high lead levels of between 39.45 and $64.34 \mathrm{wt} . \%$ and an average alkaline content $\left(\mathrm{Na}_{2} \mathrm{O}+\mathrm{K}_{2} \mathrm{O}\right)$ of only $0.67 \mathrm{wt} \%$, as shown in Table 1 . No significant differences in the major chemical compositions of glaze samples between the two ceramic production sites could be observed. There were several primary methods by which the transparent high lead glazes could be produced. The first involved a lead compound such as black litharge $(\mathrm{PbO})$, galena $(\mathrm{PbS})$, red lead $\left(\mathrm{Pb}_{3} \mathrm{O}_{4}\right)$ or white lead $\left(2 \mathrm{PbCO}_{3} \cdot \mathrm{Pb}(\mathrm{OH})_{2}\right)$ being applied by itself to the surface of the pottery body as a suspension in water. In the second method, a mixture of lead oxide $(\mathrm{PbO})$ with silica in the form of quartz sand, ground quartz, chert pebbles or clay was applied. A third method was characterized by pre-fritting the lead compound and silica together and then grinding the frit to power, which was then applied. Within any of these methods, a small amount of clay might be added to the glaze suspension (Tite et al. 1998).

Examining interactions between the ceramic glaze and body by chemical analysis of glaze and body can provide evidence for the glazing techniques used (Tite et al. 1998; Walton and Tite 2010). If the lead compound is applied directly onto the surface of the ceramic body, the lead diffuses into the body during firing and reacts with the body to form a glaze. In this way, the silica and alumina content of the glaze composition is actually drawn from the body. This suggests that if the $\mathrm{PbO}$ contents and any intentionally added colorant such as $\mathrm{CuO}$ are subtracted from the glaze composition, which is then renormalized to $100 \%$, the adjusted glaze composition should match that of the body. If a mixture of $\mathrm{PbO}$ and silica is applied, the lead and silica react together with the body during the glazing process. In this process, some components of the body such as aluminium, calcium, iron and the alkalis diffuse into the glaze. This should result in the silica contents of the renormalized glaze being higher than that of the body, while the alumina and other oxide contents should be lower. If the lead compound is mixed with the body clay to make the glaze suspension, then the adjusted glaze composition would again tend to match that of the body (Walton and Tite 2010).

In order to consider in more detail the likely glazing techniques, the major chemical compositions of the bodies of six Tang sancai fragments from the Huangpu and Huangye kilns were analysed using a JEOL JXA-8200 electron microprobe, the results are also given in Table 1. The plots of recalculated silica and alumina contents in the glazes versus their corresponding bodies are shown in Figure 2. All the recalculated silica contents of the Tang sancai glazes from both the Huangpu and Huangye kilns were higher than those of their ceramic bodies, while the recalculated alumina contents of glazes were lower than those of their bodies. This indicates that a mixture of lead compound with silica was used to make the Tang sancai glazes at both the Huangye and Huangpu kilns.

Furthermore, as seen in Table 1, the glazes produced in the Huangpu and Huangye kilns both had a significant amount of alumina, averaging 6.84 and $6.18 \mathrm{wt} . \%$ respectively. While a small volume of alumina probably diffused into the glaze from the ceramic body, the high alumina contents found in these Tang sancai glazes implies that it is highly likely to have been added to the glaze recipe deliberately in the form of clay. A similar glaze recipe was thus likely to have been used at both kilns: a lead-silica (quartz sand or quartz)-clay mixture. The similarity 

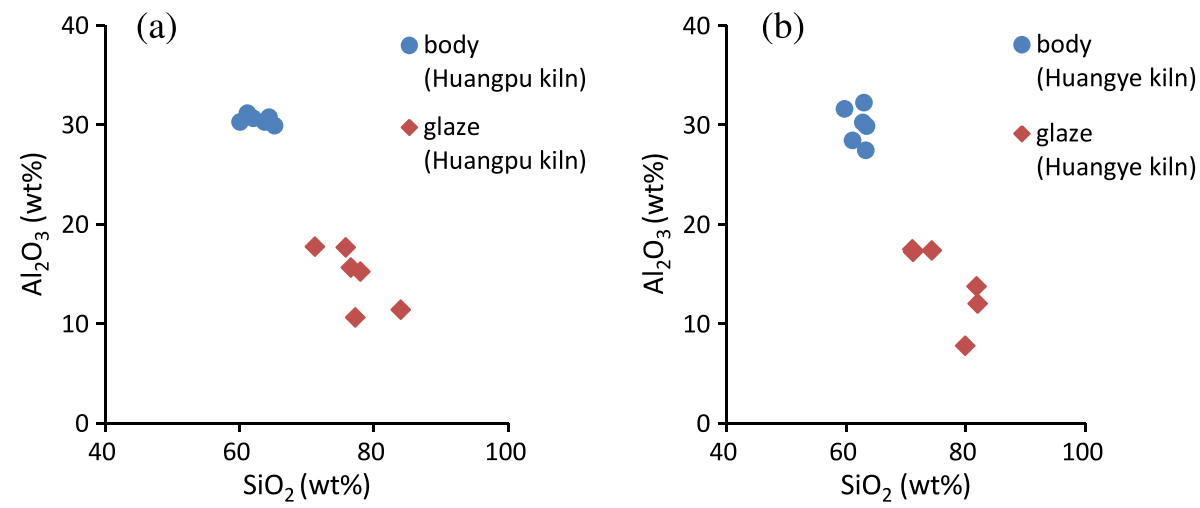

Figure 2 Plots of glaze compositions recalculated by removing $\mathrm{PbO}$ and $\mathrm{CuO}$ contents versus the corresponding body compositions of Tang sancai from the Huangpu and Huangye kilns. [Colour figure can be viewed at wileyonlinelibrary. com]

between glazing techniques used to produce Tang sancai glazes at the two kilns suggests that some communication occurred between them; another possibility is that the potters in each region developed the application of lead-silica-clay mixture independently based on an earlier lead-glazing technique.

\section{Comparison and provenance of Tang sancai glazes by trace elemental compositions}

The trace element compositions of Tang sancai glazes discussed here are shown in Table 2. Based on Goldschmidt's rule in geochemistry (Goldschmidt 1937), all the elements in the periodic table can be divided into four categories: lithophile elements, which concentrate in silicate phases; chalcophile/sulfophile elements, which concentrate in sulfides; siderophile elements, which concentrate in metallic iron; and atmophile elements, which naturally occur as gaseous elements such as nitrogen and the inert gases. Elements that belong to the same category enrich each other during the process of crust formation, smelting, ore-forming and other geochemical processes; thus, they have similar geochemical characteristics. Based on this, all the trace elements in the Tang sancai glazes measured in this study were divided into the following three categories:

- Lithophile elements: Li, B, Ti, V, Cr, Rb, Sr, Y, Zr, Nb, Cs, Ba, Hf, Th, U and REE elements.

- Chalcophile elements (sulfophile): Zn, As, Sn and Sb.

- Siderophile elements: Co and Ni (Ti can also be associated with Fe).

The Tang sancai lead glazes made in the Huangpu and Huangye kilns were made with essentially four components: the two siliceous matrices (quartz sand/ground quartz and clay), the flux (lead compound) and the colorants (copper ore, bronze, ochre or other iron-bearing minerals). Therefore, in light of Goldschmidt's rule, the contents of lithophile trace elements in Tang sancai glazes were introduced mainly with the two siliceous matrices of the glaze recipe, and the contents of chalcophile trace elements were mainly introduced by the lead flux and colorants. The trace elements of the glaze samples thus could be divided into subgroups to allow separate discussion of the siliceous raw materials and the lead compound flux.

The chalcophile elements, $\mathrm{Zn}, \mathrm{As}, \mathrm{Sn}$ and $\mathrm{Sb}$, are common accompanying elements in lead ore deposits. In addition, the copper- and iron-bearing colorant components in green- and browncoloured glazes might also contribute certain concentrations of $\mathrm{Zn}, \mathrm{As}, \mathrm{Sn}$ and $\mathrm{Sb}$. The primary 


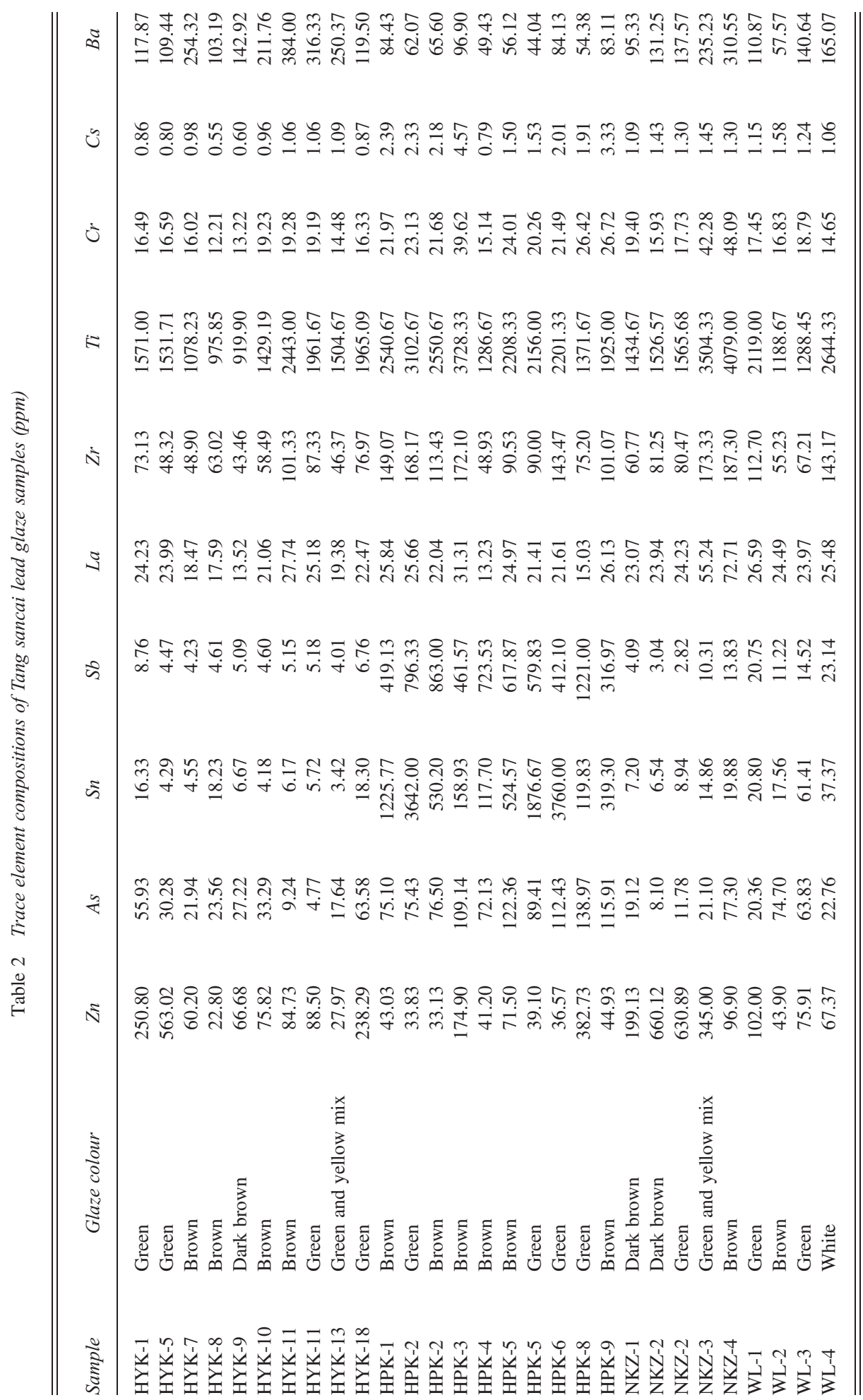


question to be asked is therefore whether the lead compound or the colorant component is the one making the dominant contribution of $\mathrm{Zn}, \mathrm{As}, \mathrm{Sn}$ and $\mathrm{Sb}$ to the glaze. As mentioned previously, $\mathrm{FeO}$ was used as a colorant for the paler brown glaze, while the dark brown colour is more likely to have been caused by the presence of $\mathrm{CuO}$ and $\mathrm{FeO}$ together; the green colour was caused by $\mathrm{CuO}$. The absolute amounts of $\mathrm{Zn}$ (Table 2) and the $\mathrm{Zn} / \mathrm{As}$ ratios (Fig. 3, a) in the glazes show that almost all green- and dark brown-coloured glazes have higher $\mathrm{Zn}$ concentrations than those of the paler brown glazes. In addition, trace element concentrations in both green and brown glazes in samples HYK-11, HPK-2, HPK-5 and NKZ-2 show that the green colour has higher $\mathrm{Zn}$ concentrations than detected in brown glaze. These results indicate that, for the green- and dark brown-coloured glazes, the $\mathrm{Zn}$ concentrations were mainly contributed by the copperbearing colorant component, which may be copper ore deposits with impurities of zinc, or bronze. The Huangpu kiln glazes have much higher amounts of Sn (Table 2 and Fig. 3, b) than that of Huangye kiln glazes and the glazes excavated from the two Tang tomb sites. Most green glazes of Huangpu kiln have a high Sn amount $>1000$ ppm, indicating that the high Sn content
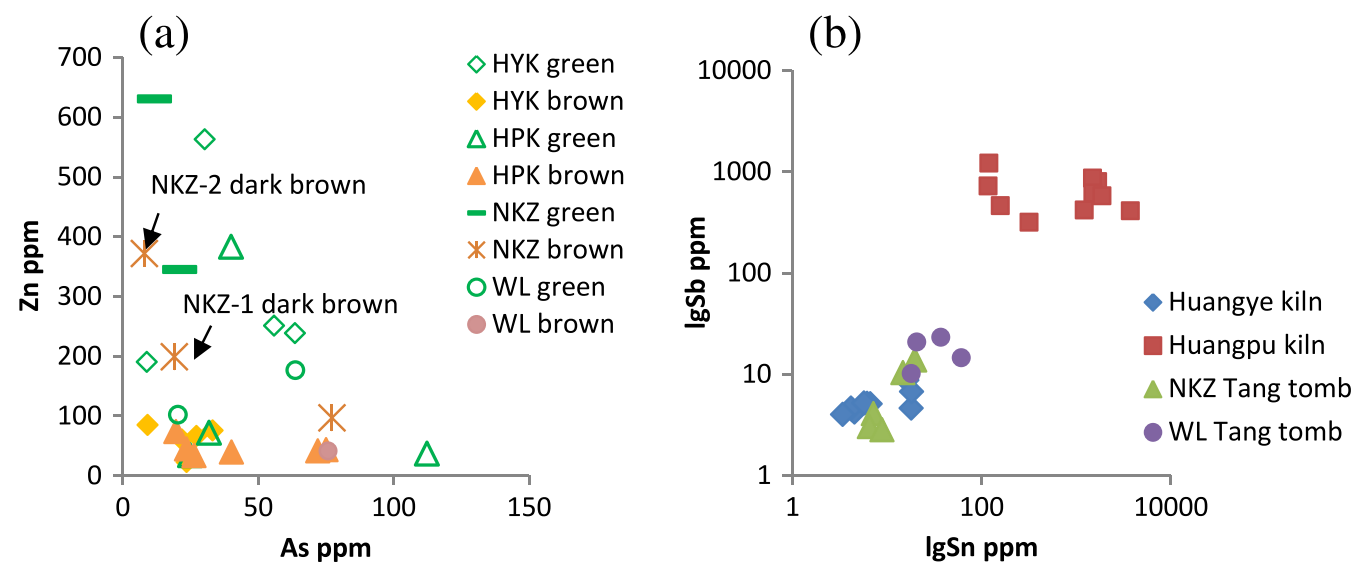

(c)

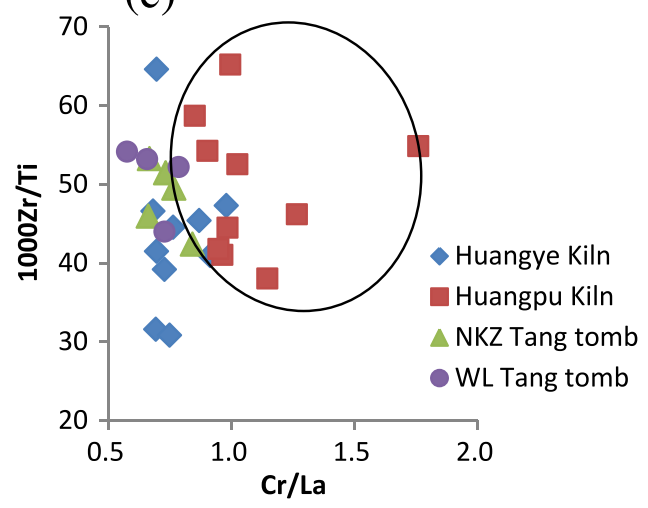

(d)

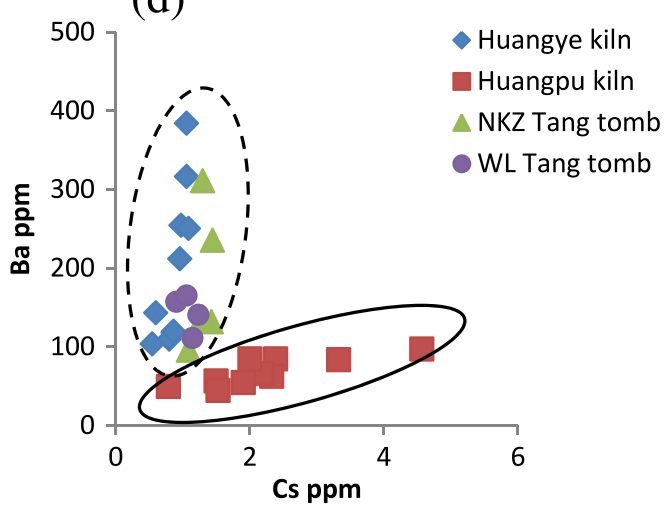

Figure 3 Plots of trace elements in Tang sancai glaze samples from the Huangye (HYK) and Huangpu (HPK) kilns and two Tang tombs: Nankezhan (NKZ) tomb and Weilaichubanshe (WL) tomb. HYK green for Huangye kiln green glazes; HYK brown for Huangye kiln brown glazes; HPK green for Huangpu kiln green glazes; HPK brown for Huangpu kiln brown glazes; NKZ green for NKZ tomb green glazes; NKZ brown for NKZ tomb brown glazes; WL green for WL tomb green glazes; and WL brown for WL tomb brown glazes. [Colour figure can be viewed at wileyonlinelibrary.com] 
could derive from the copper-tin compound used as a colorant. This suggests that the sources of copper-rich materials used in Huangpu kiln green glazes are different from that used in Huangye kiln glazes and the glazes excavated from the two Tang tomb sites.

For the other Huangpu kiln glazes, their Sn content would mainly be influenced by the lead compound. No distinctions in As and Sb concentrations could be identified amongst different glaze colours; differently coloured areas of the same glaze sample had similar concentrations of As and $\mathrm{Sb}$. This indicates that As and $\mathrm{Sb}$ concentrations were also mainly influenced by the lead compound. As seen by the $\mathrm{Sn} / \mathrm{Sb}$ ratios of Tang sancai lead glazes in Figure 3(b), Huangpu kiln glazes have higher concentrations of $\mathrm{Sb}$ and $\mathrm{Sn}$ than the Huangye kiln glazes and the glazes excavated from the two Tang tomb sites, yet no distinction in terms of $\mathrm{PbO}$ concentrations in glazes could be found between glazes from the two kilns or the two Tang tomb sites. The lead compound used in lead glaze production is extracted and refined from lead sulphide minerals or $\mathrm{PbO}$ minerals. Therefore, when compared with the source of lead compound used in Huangye kiln lead glazes, those used to make the Huangpu kiln glazes had higher concentrations of Sb and $\mathrm{Sn}$ impurities. In addition, relatively low and similar concentrations of $\mathrm{Sb}$ and $\mathrm{Sn}$ found in glazes from the NKZ and WL tombs as well as the Huangye kiln suggest that a lead ore deposit with similar geological characteristics was used to produce all these lead glazes.

The concentrations of lithophile trace elements in a lead glaze mainly derive from its siliceous matrices (quartz/sand and clay). It has been proven that some trace elements have a potential to characterize the siliceous raw materials used for making glasses and ceramic body at different production sites, such as Zr-Ti-Cr-La (Henderson et al. 2016; Shortland et al. 2007) and Zr-Ba (Oikonomou et al. 2016). The elements $\mathrm{Zr}$, Ti, Cr and La are generally related to various minerals such as zircon $(\mathrm{Zr})$, rutile $(\mathrm{Ti})$, ilmenite $(\mathrm{Ti})$, monazite $(\mathrm{La})$, chromite $(\mathrm{Cr})$ and barite $(\mathrm{Ba})$. Cs can substitute for $\mathrm{K}$ in the mica and $\mathrm{K}$-feldspar. Thus, their concentrations vary in a way that reflects the local geology of the sand and clay precursors used to make the glaze (Oikonomou et al. 2016). The ratio plots of $\mathrm{Cr} / \mathrm{La}$ versus $1000 \mathrm{Zr} / \mathrm{Ti}$ and a plot of $\mathrm{Cs}$ versus $\mathrm{Ba}$ in Tang sancai glaze samples are shown in Figures 3(c, d). In Figure 3(c) the Huangpu kiln glazes can be seen to group separately from the Huangye kiln glazes based on relatively higher $\mathrm{Cr} / \mathrm{La}$ ratios. A more obvious distinction between the lead glazes made in these two kilns can be found in the $\mathrm{Cs} / \mathrm{Ba}$ ratios (Fig. 3, d). This indicates that the lead glazes from the Huangpu and Huangye kilns were made from different siliceous raw material sources (probably local sand and clay) and that the glazes can thus be discriminated from each other by means of the trace element ratio plots $\mathrm{Cr} / \mathrm{La}$ versus $1000 \mathrm{Zr} / \mathrm{Ti}$ and $\mathrm{Cs}$ versus $\mathrm{Ba}$. The glazes of the Tang sancai fragments excavated from the two Tang tomb sites group within the same plot area as the Huangye kiln glaze samples (Figs 3, c, d). This indicates that the siliceous raw materials used to produce these glazes might originate from the same geological region.

Both the lead ore deposits and siliceous raw materials used to make the Tang sancai glaze samples excavated from the NKZ and WL Tang tombs in Xi'an City have similar geological characteristics to those used in Huangye kiln glazes. This is a strong indication that the Tang sancai wares found in the NKZ and WL Tang tombs were made in Huangye kiln near Luoyang City and that they were traded to Xi' an City.

As indicated by the discussion above, trace element analysis of glazes can potentially be used to associate Chinese Tang sancai wares of unknown origin with their production centres. However, note that as the lead glaze is composed of three parts, the siliceous raw material, the lead compound and colorant, although the contents of lithophile elements in the glaze are mainly derived from the siliceous raw material, a small proportion may derive from the lead compound. In addition, a small part of the trace element composition of the glaze may have diffused from the 
clay body, although in most cases the same clay source would have been used in the glaze and its ceramic body. Thus, the multiple components of glaze may weaken the trace element distinctions between the siliceous raw materials with different geographical and geological sources used in different production sites. Nevertheless, trace element analysis can still be used as a complementary method to uncover the provenance and sources of raw materials used in glaze production in some cases, based on this study.

\section{Comparison and provenance of Tang sancai glazes using lead isotope ratios}

The lead isotope ratios of Tang sancai lead glaze samples determined in this study are shown in the plots of ${ }^{208} \mathrm{~Pb} /{ }^{206} \mathrm{~Pb}$ versus ${ }^{207} \mathrm{~Pb} /{ }^{206} \mathrm{~Pb}$ and ${ }^{206} \mathrm{~Pb} /{ }^{204} \mathrm{~Pb}$ versus ${ }^{207} \mathrm{~Pb} /{ }^{206} \mathrm{~Pb}$ in Figure 4. The lead isotope ratios in different ore deposits have distinctive characteristics depending on their geological age and geological region in which each was produced; this natural variation in lead isotope ratios has the potential to identify the provenance of archaeological materials (Wolf et al. 2003). It is evident that the Tang sancai glazes produced in the Huangpu and Huangye Kilns can be grouped separately based on their different lead isotope ratios. This indicates that different ore sources were exploited by each kiln (Figs 4, a, b). The lead isotope ratios of the Tang sancai
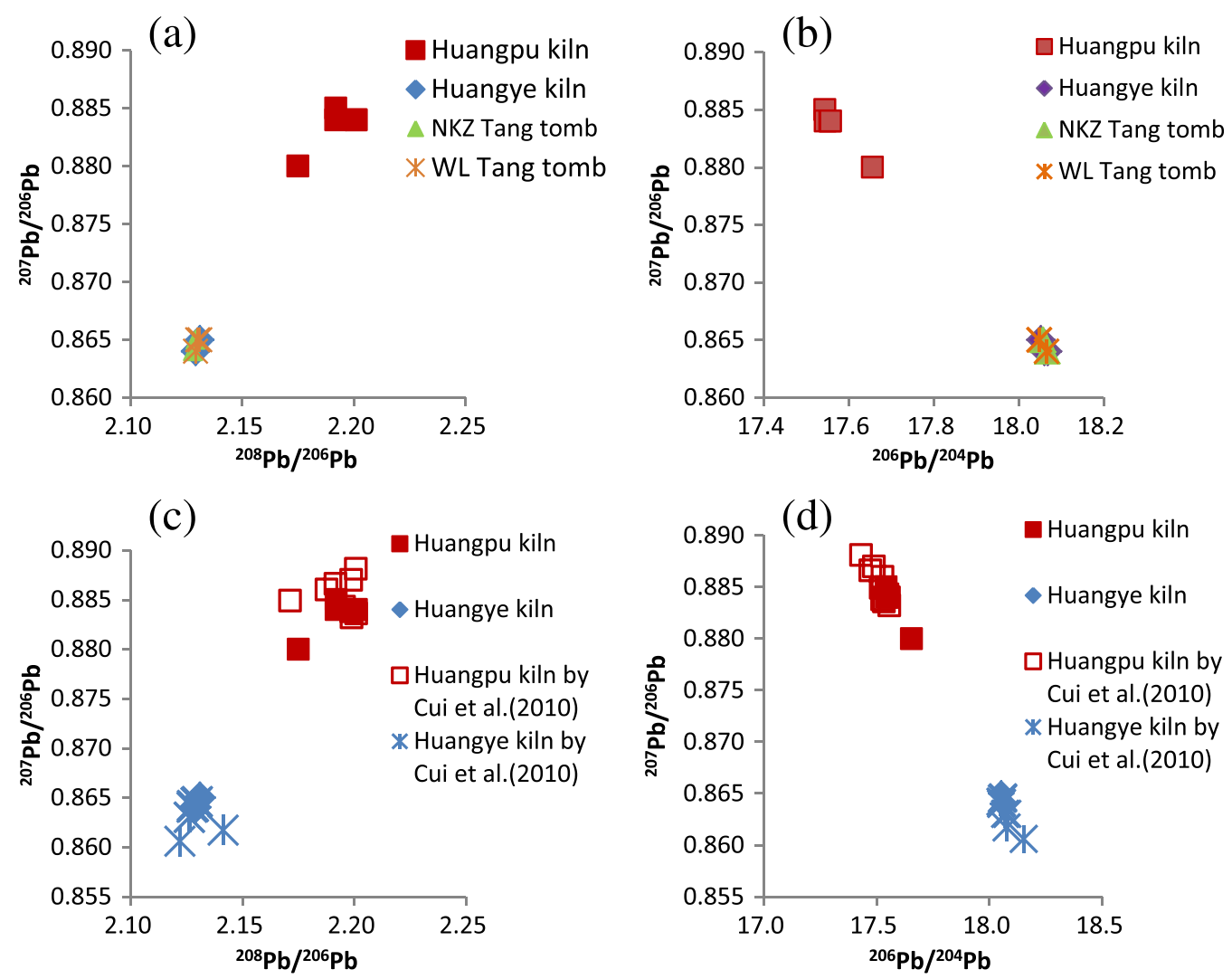

Figure 4 Lead isotopic ratios for Tang sancai lead glazes from the Huangpu and Huangye kilns and the Nankezhan (NKZ) and Weilaichubanshe (WL) tombs in this study, and for Tang sancai lead glazes made in the Huangpu and Huangye kilns taken from Cui et al. (2010). [Colour figure can be viewed at wileyonlinelibrary.com] 
glazes analysed in this study were in accordance with those analysed by Cui et al. (2010), which were plotted together with the data analysed in this study, in Figures 4(c, d).

As seen in Figures 4(c, d), the lead isotope ratios of the glaze samples made in Huangye kiln were distributed in a very narrow range, which suggests that a single lead ore source or different ore sources with similar geochemical characteristics were used for glaze-making. This suggests that the Huangye kiln potters may have exploited lead ore deposits from a restricted geological area. For the Huangpu kiln glaze samples, a possible mixing line of lead isotope ratios can be seen in Figures 4(c, d). There are two possible reasons for this mixing line: a variation within the same lead ore source used or that more than one lead source with different $\mathrm{Pb}$ isotope ratios was used for Huangpu kiln glaze-making. However, this is only tentative evidence for the mixing of lead sources for Huangpu kiln glazes because to date no helpful lead isotopic ratios of lead ore deposits in Shaanxi and Henan provinces, where the Huangpu kiln and Huangye kilns are located respectively, have been published. Further research is necessary to provide more rigorous evidence.

The Huangpu and Huangye kilns were the most productive and significant production centres for Tang sancai wares in China. Although the exact lead ore sources used to produce Tang sancai glazes have not been determined, it is obvious that different lead ore sources were used in the two kilns, as demonstrated by their distinct lead isotope ratios. This is a strong indication that lead isotopic ratios of Tang sancai glazes might be a potential tool to determine the provenance of Tang sancai wares excavated from archaeological tombs and sites.

The lead isotope ratios of Tang sancai glaze samples excavated from the NKZ and WL tombs are also plotted in Figures 4(a, b). All five glaze samples were distributed within the Huangye kiln glaze group, indicating that the tomb glazes were probably made using the same lead ore source as used to make Huangye kiln glazes and probably made in the Huangye kiln. This indication is well supported by the trace element characteristics of the Tang sancai lead glazes discussed above.

\section{Trade of Tang sancai wares produced in the Huangye and Huangpu kilns}

Until now, most tombs that have produced Tang sancai wares were distributed across two areas: Chang'an (present-day Xi'an City), which was the capital of the Tang dynasty, and Luoyang City, which served as the second capital during the Tang period (Jiang 2009, 21). Huangpu kiln, located near Xi'an, and Huangye kiln, located near Luoyang, were two important Tang sancai ware production centres that supplied a large amount of sancai wares not only to Xi'an and Luoyang but also to other places in ancient China and the wider world (Wood 2011, 203). Based on the trace element analysis and lead isotope ratios of Tang sancai glazes discussed above, all the Tang sancai samples excavated in the WL and NKZ tombs have a high likelihood of having been produced by Huangye kiln near Luoyang City rather than in the local Huangpu kiln near Xi' an. This shows that some Tang sancai wares produced in Huangye kiln were traded to Xi' an. This deduction can be supported by previous studies (Lei, 2007; Lei et al., 2007). Based on the combination of the archaeological studies with trace element analysis of Tang sancai bodies, the results suggest that although the studied Tang tombs of Li Fu (AD 675), Li Hui (689) and Kang Wentong (697) were all located close to Xi'an, the body samples of Tang sancai, both from the tombs and from Huangye kiln, have similar compositions, suggesting they were made in Henan at the Huangye kiln and were traded to Xi'an. Besides, they also found that for Tang sancai wares unearthed in the Tang tombs in Xi' an dating back to before 705 when Empress Wu Zetian gave up the throne, almost all Tang sancai wares were made in Huangye kiln. However, for the 
Tang sancai wares from the Xi'an tombs that can be dated to after 705 , examples made in Huangye and Huangpu kilns have been identified.

Results from excavations have shown that the Huangye kiln started to produce Tang sancai wares in the early Tang period and this production was sustained throughout the whole Tang period. The Huangpu kiln only began to produce the wares from the Prospering Tang period (649-756). No evidence found so far shows that the Tang sancai made in Huangpu kiln near Xi' an was ever traded to Luoyang City. However, as the above discussion shows, some evidence implies that the Tang sancai made in Huangye kiln near Luoyang City might have been traded to Xi' an. This suggests that, during the early Tang period, Huangye kiln was the most important Tang sancai production centre. After 705, when Empress Wu Zetian gave up the throne, the political and economic centres shifted from Luoyang to Xi' an, which led to the development of Huangpu kiln near Xi' an. The Huangpu kiln then evolved gradually into another significant Tang sancai production centre.

\section{CONCLUSIONS}

By comparing adjusted glaze compositions with their respective body compositions, the same lead glazing technique was identified as having been applied to the Tang sancai glazes produced in both Huangpu and Huangye kilns, being based on a mixture of lead-silica (quartz sand or quartz) and clay.

The Tang sancai lead glazes produced in Huangpu and Huangye kilns could be distinguished from each other by means of their distinct trace element compositions and lead isotope ratios. The sources of lead ore deposits used in the glazes from the two kilns were different according to their lead isotope ratios and concentrations of the chalcophile trace elements, $\mathrm{Sn}$ and $\mathrm{Sb}$. The siliceous raw materials used to make Tang sancai glazes from these two kilns could be discriminated from each other by the ratio plots $\mathrm{Cr} / \mathrm{La}$ versus $1000 \mathrm{Zr} / \mathrm{Ti}$ and $\mathrm{Cs}$ versus $\mathrm{Ba}$.

Lead isotope comparisons combined with trace elemental analysis of glazes could be a helpful method for determining a provenance for Tang sancai artefacts found in a wide range of archaeological contexts and linked to the two kiln sites investigated here. Such research will also highlight kiln products not made in Huangpu and Huangye kilns.

Investigation of the provenance of Tang sancai glazes of uncertain origin found in Xi' an were shown to have been produced in Huangye kiln near Luoyang City and then traded to Xi' an.

\section{ACKNOWLEDGEMENTS}

Strontium and lead isotope analyses were funded by a successful application to the NIGFC committee at BGS (grant number IP-1487-1114; P.I. J. Henderson). LA-ICP-MS analysis were conducted under the joint Centre for Environmental Geochemistry, University of Nottingham-British Geological Survey research program. Simon Chenery publishes with the permission of the Director, British Geological Survey.

\section{REFERENCES}

Cui, J. F., and Lei, Y., 2009, A primary study on the provenance and technology of the yellow glazes of Tang sancai potteries unearthed from Tongchuan Huangpu kiln and Huangye kiln (铜川黄堡窑与黄治窑出土唐三彩黄釉的产地与 工艺初步研究), Conference proceedings of 2009 International Symposium on Ancient Ceramics, 95-100.

Cui, J. F., Lei, Y., Jin, Z. B., Huang, B. L., and Wu, X. H., 2010, Lead isotope analysis of tang sancai pottery glazes from Gongyi kiln, Henan province and Huangbao kiln, Shaanxi province, Archaeometry, 52(4), 597-604.

Feng, X. Q., Feng, S. L., Sha, Y., and Jakšić, M., 2005, Study on the provenance and elemental distribution in the glaze of Tang sancai by proton microprobe, Nuclear Instruments and Methods in Physics Research, Section B: Beam Interactions with Materials and Atoms, 231(1-4), 553-6. 
Goldschmidt, V. M., 1937, The principles of distribution of chemical elements in minerals and rocks, Journal of the Chemical Society, 655-73.

Gongyi City Institute of Cultural Relics, 2000, Excavations of the Tang sancai Kiln at Huangye (黄冶唐三彩窑), Science Press, Beijing.

Henderson, J., Chenery, S., Faber, E., and Kröger, J., 2016, The use of electron probe microanalysis and laser ablationinductively coupled plasma-mass spectrometry for the investigation of 8th-14th century plant ash glasses from the Middle East, Microchemical Journal, 128, 134-52.

Jia, Z. M., and Jia, Y. L., 1987, Brief report on the survey made on the Xing kiln in Neiqiu county, Hebei province (河北 省內丘县邢窑调查简报), Wenwu, 9, 1-0.

Jiang, Q., 2009, Tang sancai, unpublished D.Phil. thesis, University of Oxford.

Lei, Y., 2007, Instrumental neutron actication analysis of Tang sancai ware and a study of its trajectory of development in the region of the capitals (唐三彩的仪器中子活化分析其在两京地区发展轨迹的研究), Palace Museum Journal, 131(3), 86-127.

Lei, Y., and Feng, S. L., 2002, Study of the compositional differences among different kilns' sancai of Tang Dynasty by SRXRF (不同产地唐三彩的SRXRF无), Nuclear Techniques, 25(10), 822-6.

Lei, Y., Feng, S. L., Feng, X. Q., Fan, D. Y., Xu, Q., Sha, Y., Cheng, L., Chai, Z. F., Jiang, J., Zhuo, Z. X., Zhang, S. L., and Liao, Y. M., 2005, Study on the compositional differences of Tang sancai from different kilns by INAA, Journal of Archaeological Science, 32(2), 183-91.

Lei, Y., Feng, S. L., Feng, X. Q., and Chai, Z. F., 2007, A provenance study of Tang sancai from Chinese tombs and relics by INAA, Archaeometry, 49(3), 483-94.

Miao, J. M., and Lu, S. L., 2001, The provenance study of Tang sancai wares by INNA and major chemical analysis (中 子活化分析和主成份分析对唐三彩产地问题的研究), Southeast Culture, 149(9), 83 - 93.

Oikonomou, A., Henderson, J., Gnade, M., Chenery, S., and Zacharias, N., 2016, An archaeometric study of Hellenistic glass vessels: evidence for multiple sources, Archaeological and Anthropological Sciences, 10, 97-110.

Rawson, J., Tite, M., and Hughes, M. J., 1989, The export of Tang sancai wares: some recent research, Transactions of the Oriental Ceramic Society, 52, 39-61.

Shaanxi Provincial Institute of Archaeology, 1992, Excavation of Tang kiln-site at Huangpu in Tongchuan, Shaanxi (唐代 黄堡窑址), Cultural Relics Press, Beijing.

Shaanxi Provincial Institute of Archaeology, 2008, Excavation of Tang kiln-site at Liquanfang in Chang'an Capital City, Shaanxi (唐长安醴泉坊三彩窑址), Cultural Relics Press, Beijing.

Shortland, A., Rogers, N., and Eremin, K., 2007, Trace element discriminants between Egyptian and Mesopotamian Late Bronze Age glasses, Journal of Archaeological Science, 34(5), 781-9.

Sun, X. M., 2002, Discovery and Research on Huangye Tang sancai kiln site at Gongyi (巩义黄冶唐三彩窑址的发现与 研究), in Tang sancai Wares of the Tang Dynasty from Huangye in Gongyi (巩义黄冶唐三彩) (ed. Henan Provincial Institute of Archaeology), Elephant Press, Zhengzhou.

Thirlwall, M. F., 2002, Multicollector ICP-MS analysis of Pb isotopes using a ${ }^{207} \mathrm{~Pb}-{ }^{204} \mathrm{~Pb}$ double spike demonstrates up to $400 \mathrm{ppm} / \mathrm{amu}$ systematic errors in Tl-normalization, Chemical Geology, 184(3-4), 255-79.

Tite, M. S., Freestone, I., Mason, R., Molera, J., Vendrell-saz, M., and Wood, N., 1998, Lead Glazes in Antiquity? Methods of Production and Reasons for Use, Archaeometry, 40(2), 241-60.

Walton, M. S., and Tite, M. S., 2010, Production technology of Roman lead-glazed pottery and its continuance into late antiquity, Archaeometry, 52(5), 733-59.

Watson, O., 2014, Ceramics from Islamic Lands, Thames \& Hudson, London.

Wolf, S., Stos, S., Mason, R., and Tite, M. S., 2003, Lead isotope analyses of Islamic pottery glazes from Fustat, Egypt, Archaeometry, 45(3), 405-20.

Wood, N., 2011, Chinese glazes: Their origins, chemistry, and recreation, University of Pennsylvania Press, Philadelphia.

Zhang, F. K., and Zhang, Z. G., 1980, Low-temperature coloured glazes of successive dynasties in ancient China (中国历 代低温色釉的研究), Journal of the Chinese Ceramic Society, 8(1), 9-19.

\section{SUPPORTING INFORMATION}

Additional supporting information may be found online in the Supporting Information section at the end of the article.

Table S1. Lead isotope ratios of Tang sancai lead glaze samples 